\begin{tabular}{|lcccccc|}
\hline \hline $\begin{array}{l}\text { Social Work/Maatskaplike } \\
\text { http://socialwork.journals.ac.za/pub }\end{array}$ & Werk & Vol 51 No 3; & Issue & 2 \\
\hline
\end{tabular}

\title{
CHALLENGES FACED BY SOCIAL WORKERS WORKING IN CHILD PROTECTION SERVICES IN IMPLEMENTING THE CHILDREN'S ACT 38
}

\section{OF 2005}

Sipho Sibanda, Antoinette Lombard

\section{Abstract}

The transition from the Child Care Act 74 of 1983 to the Children's Act 38 of 2005 has been chaotic. This has been caused by shortcomings in the new legislation; challenges faced by social workers in adapting to it; lack of capacity of the stakeholders in the field; and the shortage of resources to implement it. The Children's Act 38 of 2005 needs to be amended to address its pre-statutory, statutory and post-statutory shortcomings. Recommendations on addressing these challenges include the establishment of a kinship care grant; amending the Children's Act; and addressing technical issues on the implementation of the Children's Act 38 of 2005. 



\section{CHALLENGES FACED BY SOCIAL WORKERS WORKING IN CHILD PROTECTION SERVICES IN IMPLEMENTING THE CHILDREN'S ACT 38 OF 2005}

\section{Sipho Sibanda, Antoinette Lombard}

\section{INTRODUCTION}

In order to reverse the legacy of apartheid, the democratically elected South African government had a tremendous task of addressing the inequalities it inherited from its predecessors (Hölscher, 2008). The process commenced with the adoption of a developmental approach as a new perspective for achieving social justice and human rights (Patel, 2008). The mandate for developmental services is outlined in the White Paper for Social Welfare of 1997. This mandate entails a deliberate shift from a "racial, paternalist and residual apartheid welfare system ... to the developmental approach which was intended to modernise the welfare system to be inclusive and more appropriate in meeting the needs of all South Africans" (Patel, 2005 in Lombard \& Kleijn, 2006:213). Child protection services are included in the "basket of developmental social welfare service delivery" (Lombard \& Kleijn, 2006:214).

The new South African government has remained true to its "first call for children" and its prioritisation of children's issues (UNICEF, 1990). This is evident in the fact that "It has enshrined children's rights in its Constitution (1996) and ratified the UN Convention on the Rights of the Child (1989) in 1995 and the African Charter on the Rights and Welfare of the Child (1990) in 2000" (September \& Dinbabo, 2008:113). In order to realise and harmonise these commitments in domestic law and to suit the new developmental paradigm, the government introduced the Children's Act 38 of 2005. Forty-three sections of this new legislation came into effect on 1 July 2007 (Republic of South Africa, 2007). The rest of the Act, including the parts of most relevance to the care and protection of children, were effected on 1 April 2010. Two sets of regulations in relation to the Children's Act 38 of 2005 have also been published (Department of Justice and Constitutional Development, 2010; Department of Social Development, 2010). The new Children's Act 38 of 2005 replaced the Child Care Act 74 of 1983 (referred to as the previous Child Care Act in this article), which was legislation that originated during the apartheid period (September \& Dinbabo, 2008).

Since the introduction of the Children's Act 38 of 2005 and its subsequent coming into effect in April 2010, there has been instability in rendering child protection services (Hall \& Proudlock, 2011; Loffell, 2011; Proudlock \& Debbie, 2011). This state of affairs has been caused by some serious shortcomings in the new legislation as well as by challenges faced by social workers in adapting to it. Most of these shortcomings relate to the grounds for finding children in need of care and protection, and the fundamental change to a court based system of renewing the placement of children (Hall \& Proudlock, 2011; Loffell, 2011). This paper reports on a study by Sibanda (2013) on the challenges which face social workers working in child protection in implementing the Children's Act 38 of 2005. 
The paper begins with a contextualisation of child protection within the Children's Act 38 of 2005 from a developmental perspective. The following section discusses the strengths and shortcomings of the Children's Act, followed by an outline of the research methods applied to the study and a presentation of the research findings and the conclusions of the study. Finally recommendations are made for effective implementation of the Children's Act 38 of 2005.

\section{CHILD PROTECTION WITHIN THE CHILDREN'S ACT FROM A DEVELOPMENTAL PERSPECTIVE}

The Children's Act 38 of 2005 is a comprehensive piece of legislation with the purpose of affording children the necessary care, protection and assistance to ensure that they can develop to their full potential (Department of Social Development, 2010). The Children's Act 38 of 2005 was prepared after the realisation that the previous Child Care Act 74 of 1983 was too narrow in focus and failed to live up to the standards of a new South Africa. It was premised on separate services for children based on the colour of their skin; in other words, it racially segregated blacks (including Indian, Coloured and African) from the rest of the population (Dawes, 2009). Although these provisions were removed with an amendment in 1996, a more radical change was required to give effect to the rights provided to children in terms of section 28 of the 1996 Constitution (Dawes, 2009). More so, it advocated for residual services whereby the state was supposed to intervene after the need had already arisen, thus when a child had already suffered from abuse, neglect or exploitation (Dawes, 2009).

Developmental social welfare principles which are stipulated in the Children's Act 38 of 2005, which social workers should apply when rendering services to children and their families, include participation, universal access, social integration, self-reliance, empowerment, appropriateness and accessibility (Department of Social Development, 2011). The Children's Act 38 of 2005 provides a wide scope to the rights and welfare of children and seeks to counter the narrow focus of the previous Child Care Act by aligning itself with the principles of developmental social welfare in the areas of giving effect to the constitutional rights of children (Constitution of South Africa, 1996), including participating in decisions affecting them.

Sections 9.1 and 9.4 of the Constitution of the Republic of South Africa (Act 108 of 1996) contain a Bill of Rights which also applies to children. In addition, section 28 of the Bill of rights deals principally with children's rights (Department of Social Development, 2006). Section 28 specifies that every child has the right to family care, parental care or appropriate alternative care; the right to be protected from abuse, neglect, maltreatment and degradation; the right to social services; and the right to have their best interests given paramount importance in all matters concerning them (Proudlock \& Jamieson, 2008). This line of thought is reflected in section 7 of the Children's Act 38 of 2005, which stipulates the best interest of the child as the standard.

According to Wexler (2003), from a developmental perspective, social workers inform clients of their right to information, participation and decision making, including the right to legal representation. Van Niekerk (1998) stipulates that the child and the family 
have a right to know in what way statutory intervention will lead to the protection of a child. The community has a right to indicate how it can protect the child by keeping him or her in the community (Lombard \& Kleijn, 2006).

Universal access is one of the key principles of the developmental approach. According to the Department of Social Development (2011:12), "Developmental social welfare services should be available to all vulnerable groups." The Children's Act 38 of 2005 defines a child as "Any person under the age of 18 " (emphasis added). This definition is now broad, comprehensive and sanctions designated social workers to provide services to non-South African children who happen to be in the Republic and are in need of care and protection.

The notion of child participation is echoed in a number of sections of the Children's Act 38 of 2005. This stems from Article 12 of the United Nations Convention on the Rights of the Child (United Nations, 1989). According to Lombard (2010:8), "Participatory democracy is a more direct form of decision making, involving those affected by decisions taken." It includes direct consultation and encourages strengths-based and empowerment approaches in service delivery (Lombard, 2010). Section 10 of the Children's Act 38 of 2005 stipulates that "Every child that is of such age, maturity and stage of development as to be able to participate in any matter ... has the right to participate in an appropriate way and views expressed by the child must be given due consideration." The child's views are paramount when finalising a children's court enquiry in terms of section 156 of the said Act. The same principle also applies when extending a court order in terms of section 159 (extension of an alternative care placement order for a period not exceeding two years); section 176 (extension of an alternative care placement order beyond the age of 18) and section 186 (extension of an alternative care placement order for a period exceeding two years). Equally significant are provisions when transferring a child to alternative care in terms of section 171 (transferring a child from one alternative care place to another one); section 174 (provisional transfer of a child from one to another form of care); and when removing a child in terms of section 173 (emergency/temporary removal of a child from one form of alternative care to another). According to section 144(3) of the Children's Act 38 of 2005, "Prevention and early intervention programmes must involve and promote the participation of families, parents, care-givers and children in identifying and seeking solutions to their problems."

From the above discussion, it is evident that the principles and key features of a developmental perspective are evident in the Children's Act 38 of 2005. This contributes to the strengths of the Children's Act 38 of 2005.

\section{STRENGTHS OF THE CHILDREN'S ACT 38 OF 2005}

The Children's Act 38 of 2005 differs significantly from the previous Child Care Act 74 of 1983 and it adequately addresses the challenges of the $21^{\text {st }}$ century. It is in alignment with the principles of developmental social welfare as envisioned in the 1997 White Paper for Social Welfare. The main strength of the Children's Act 38 of 2005 stems from its unwavering commitment to prevention and early intervention services. 
Programmes aimed at stopping abuse or neglect before it starts (prevention and early intervention services) have for the first time been clearly legislated for. Prevention and early intervention services are cost effective, because they reduce the demand for more costly services such as state alternative care in children's homes (Proudlock \& Jamieson, 2008). They are also an investment in human capital, because they ensure that children develop to their full potential. Dawes (2009:4) summarises the strengths of the Children's Act 38 of 2005 as follows: "one of the interesting features of the Act, and an advance on its predecessor, is the recognition of the importance of services to vulnerable families and children in order to reduce the probability of abuse and neglect, and the need for statutory intervention. In the previous Act the focus was on statutory care rather than early intervention and the intention of the new legislation is to shift the emphasis to the latter while strengthening statutory processes." But although this is a significant shift, it is the implementation of the Act and making it a lived reality for children and their families that is still inadequate.

In recognising the severe shortage of social workers in South Africa (Earle, 2008:5-6) and the pivotal role played by a range of other social services practitioners (e.g. child and youth care workers, auxiliary social workers and community development workers), the Children's Act 38 of 2005 replaces some references to social workers with the term "social service professionals". This was to ensure that many of the tasks restricted to social workers can be done by other social service practitioners. These tasks include assessing partial care centres and drop-in centres for registration, and monitoring longterm foster-care placements. Diversification of roles will help ensure that each category of worker is appropriately used according to their particular training and also will make services more accessible in poor and rural communities where social workers are scarce.

However, "This new approach cannot be implemented until the South African Council for Social Service Practitioners (SACSSP) and the Minister of Social Development officially recognise and register the full range of social service practitioners" (Proudlock \& Jamieson, 2008:39). Although the SACSSP newsletter for February/March 2013 indicates that a professional board for child and youth care workers (PBCYC) has been elected and appointed and that, "It will soon be inaugurated by the Minister for Social Development." To date (September 2014) this promise has not yet materialised. The fact that a range of social service practitioners is poorly developed and unrecognised leads to inevitable human resource challenges in implementing the Children's Act. Despite the abovementioned strengths, the Children's Act 38 of 2005 has numerous shortcomings.

\section{SHORTCOMINGS OF THE CHILDREN'S ACT 38 OF 2005}

Since the Children's Act 38 of 2005 has been in operation, problems have emerged in relation to temporary safe care post-removal processes; grounds for finding orphans and vulnerable children to be in need of care and protection; the change-over to a courtbased system for deciding on extension of placements; and over-reliance on the foster care system to provide income support to families caring for orphaned and abandoned children (Sibanda, 2013). All these challenges stem from the shortcomings of the 
Children's Act 38 of 2005 with regards to pre-statutory, statutory and post-statutory processes and will be discussed below.

The extension of placement orders (both foster care and institutional care) is provided for in Sections 159 and 186 of the Children's Act 38 of 2005. The responsibility for extending court orders, which were previously administratively decided on by the social workers acting under the authority of the Department of Social Development, has now been awarded to the presiding officers of the children's courts. This has led to immense pressure on the already heavily burdened social workers. According to Loffell (2011), the presiding officers require voluminous and unnecessary documents to be attached to the section 159 (extension of orders) reports. It is now all about running all over the place with little pieces of paper and the valuable professional time of social workers has now been relegated to perform clerical duties (Loffell, 2011).

It is extremely difficult for social workers managing high case loads to have all documents and attachments to reports for extending orders ready for courts on due dates. It is therefore inevitable for orders to lapse. According to Du Toit (as cited in News24, 2011), an estimated 123236 children's foster care orders had lapsed by the end of January 2011 without being extended and, in addition, a large number of such orders were due to expire each month. Seeing this catastrophe and touched by the plight of large numbers of children who were consequently facing discontinuance of foster care grants, an urgent application was made to the high court by the Centre for Child Law at the University of Pretoria. In Centre for Child Law v Minister of Social Development and others (10 May, 2011a), Classen recognised the urgent need to provide a temporary solution for pre-Children's Act foster care orders requiring renewal "until such time as the Children's Act 38 of 2005 is amended to provide for a more comprehensive legal solution". Classen also considered the problem of expired foster care orders. He instructed that those which have expired since 1 April 2010 should automatically be "deemed not to have expired and are hereby extended for a period of 2 (two) years from the date of this order" (Centre for Child Law v Minister of Social Development and others, 2011a). With orders that expired even earlier, he directed that any foster care order that expired within two years before 1 April 2010 was automatically revived and extended in the same way as those expiring after 1 April 2010. In another order, Classen added that, where a social worker operating in terms of the old administrative process decided that a placement should not be extended "for the full two year period ... or should be extended for longer than two years, the social worker may approach the Children's Court for an appropriate order in terms of the Children's Act" (Centre for Child Law v Minister of Social Development and others, 2011b). However, this temporary solution was meant only for lapsed foster-care orders and does not address the challenge of lapsed orders for children in child and youth care centres.

As mentioned earlier, the Children's Act 38 of 2005 is developmental in nature due to its emphasis on early intervention and other proactive services. Nevertheless, dilemmas faced by social workers on whether or when to remove children is a practical reality. Misjudgement and prejudicial decisions on the matter are likely to be traumatic for children and their families. Prior to removing a child, the Children's Act 38 of 2005 
requires a preliminary hearing. Section 151 of the Children's Act 38 of 2005 covers such removals with prior court approvals, whilst Section 152 provides for emergencies where there are time constraints in getting a prior court authorisation. These sections came under the spotlight in the 2011 High Court case of Chirindza and others v Gauteng Department of Social Development and others. This was after some social workers in the services of the Pretoria East Department of Social Development, escorted by the police, municipal officials and media personnel, used section 152 to forcefully remove children from men and women who were using children to gain sympathy when begging on the streets (Chirindza and others v Gauteng Department of Social Development and others, 2011). After neither being denied access to their children nor being told where they were, two of those adults, through the Centre for Human Rights at the University of Pretoria, subsequently challenged the process in the High Court (Chirindza and others $\mathrm{v}$ Gauteng Department of Social Development and others, 2011).

In his judgment Fabricius found the Children's Act 38 of 2005 to be deficient in failing to provide adequate post-removal procedures where children have been removed and placed in temporary safe care placements (Chirindza and others v Gauteng Department of Social Development and others, 2011). It should have required that the Children's Act 38 of 2005 provided for an immediate review hearing by the children's court. The purpose of such an appearance would be to determine whether the removal was in the child's best interests. It is because of this shortcoming that the High Court judge, Fabricius found and declared the Children's Act 38 of 2005 to be unconstitutional. He ordered that additional wording requiring reviews be inserted. Unfortunately, the said judge did not provide guidelines on what social workers will need to prove at the reviews. Nor did he indicate factors to be considered by presiding officers at reviews.

Notwithstanding the provisions of the Children's Act 38 of 2005 on temporary safe care, problems of immense proportions have resulted from the wording of section 150(1)(a). This section is one of the grounds for finding that a child is in need of care and protection. Section 150(1)(a) of the Children's Act 38 of 2005 states that "A child is in need of care and protection if, the child has been abandoned or orphaned and is without any visible means of support". From practice experience, this section has proved problematic when a social worker tries to open and finalise a children's court enquiry for a child in foster care whose order has lapsed. The same is true for an abandoned or orphaned child requiring foster care who has been staying with alternative parents on a private arrangement and now needs state assistance because of a small source of income that is sufficient only for themselves but not for an additional person (the child concerned). Such care givers are usually relatives receiving some form of state assistance (for example, disability grant, older persons grant, and child support grant). Besides section 150(1)(a), there is usually no other ground for finding such children "in need of care and protection." Unfortunately, most presiding officers reject the ground saying, "The child is not without 'visible means of support' as required by section 150(1)(a)" (Hall \& Proudlock, 2011:2). Such children can only be eligible for a foster care grant if the children's court issues a court order placing them in foster care (be it with a relative or a non-relative). 
Lastly, the Children's Act 38 of 2005 does not address the plight of children who are in need of cash and not much in need of care. According to Loffell (2011), a simple introduction of a "kinship care grant" can ameliorate this terrible predicament. Realising the burden on the foster care system, the Portfolio Committee on Social Development has requested in its report on the Amendment Bill that the Department of Social Development conducts a comprehensive review of the social security policy for children and the foster care system (Proudlock \& Jamieson, 2008). However, this review has not yet materialised. The present qualitative study was conducted within the context of the shortcomings of the Children's Act 38 of 2005 in order to explore the challenges that social workers face in the field of child protection.

\section{RESEARCH METHODS}

A collective case study design was utilised within a qualitative approach (Rubin \& Babbie, 2011) to gain insight into and an understanding of the challenges faced by social workers working in child protection services in implementing the Children's Act 38 of 2005. A non-probability purposive sampling technique (Rubin \& Babbie, 2011) was used to select 18 social workers involved in the implementation of child protection services, as provided for in the Children's Act 38 of 2005, from three different sectors of Johannesburg Child Welfare (JCW). Data were gathered through three focus group discussions which each comprised of six social workers and was guided by a semistructured interview schedule (Neuman, 2000). Three meetings of 60 minutes each were initially scheduled with each focus group. However, data became saturated during the second meetings, and hence the third meetings were cancelled. Data analysis was done in accordance with Creswell's (2009) thematic model.

The study has been ethically cleared by the University of Pretoria and permission was granted by Johannesburg Child Welfare to approach social workers for the study. Participation was voluntary and social workers gave their informed consent to participate in the study. This included agreeing to confidentiality. No data presented in the findings can be attached to any specific participant and hence anonymity was upheld.

Data credibility and trustworthiness were enhanced through prolonged and repeated focus group sessions until data saturation occurred (Creswell, 2009:192). Respondent validation was the most critical technique for establishing credibility. This entailed interpreting the information and then checking with the participants if the interpretation and thematic analysis were consistent, correct and congruent with their experiences (Greeff, 2011:372).

\section{FINDINGS OF THE STUDY}

The findings first present the biographical details of the participants in the study. The following section will discuss the challenges in implementing the Children's Act 38 of 2005, using themes and sub-themes which emerged from the research data.

\section{BIOGRAPHIC DETAILS OF PARTICIPANTS}

A total of 18 social workers participated in the study. Nine were male and nine were female. Twelve participants were between the ages of 25 to 30; three were between the 
ages of 31 to 35 ; two were between the ages of 36 to 40 ; one participant was above the age of 56. Of the 18 participants, 17 were black and one was coloured. Of the 18 participants, two had five years of social work experience in child protection services; seven had three years experience; four had four years of experience; one each had seven years, six years, one year and one and a half years of experience. Most of the participants had between one and three years of experience at Johannesburg Child Welfare. Of the 18 participants, seven had been implementing the Children's Act 38 of 2005 for three years; five had been implementing it for two years; two had been doing so for two and a half years; and four had been implementing the Children's Act for one to one and a half years.

\section{Theme 1: Contextualisation of child protection within the Children's Act 38 of 2005 from a developmental perspective}

Participants' responses in contextualising child protection within the Children's Act 38 of 2005 from a developmental perspective varied significantly. Some participants could not specifically define what a developmental approach to social work is. However, a few participants were very elaborate in their contextualisation of child protection within the Children's Act from a developmental perspective:

"I do believe that the Children's Act is aligned to the developmental perspective in that it calls for collaboration of many stakeholders, especially the foster parents, the social workers, the psychologists and other professionals who are there to see to it that the best interests of the children are a priority."

"The Children's Act, it stems from developmental social work, which is an approach that was adopted in South Africa as formal policy through the White Paper for Social Welfare."

"The developmental perspective, especially concerning the Children's Act, requires that social work practitioners employed by agencies render preventative work; they also render services to contain children within the families before they can even think about removing them or taking any other drastic measures. So the developmental perspective stresses that children should be retained within their families, within the immediate family, within the extended family and if not possible, within their communities; it talks about doing preventative work, raising awareness within communities to protect children."

\section{Theme 2: Institutional challenges in the implementation of the Children's Act 38 of 2005}

The participants revealed that the institutional challenges in the implementation of the Children's Act stem from the problems that social workers encounter with presiding officers. These problems include the lack of uniformity in terms of handling Children's Court matters among presiding officers; the attitude of presiding officers; unrealistic expectations from presiding officers; varying expertise of presiding officers and the insufficient number of presiding officers. Institutional challenges in implementing the 
Children's Act 38 of 2005 also stem from the attitude of social workers and from the fact that social workers have to work with untrained and uncooperative police officers. These obstacles will be discussed next as sub-themes.

\section{Lack of uniformity among presiding officers}

The majority of the participants stated that most presiding officers do not have a standardised way of doing things. Even though there are regulations in place, the regulations are not very clear. Hence presiding officers are ambiguous, which is exacerbated by the Children's Act 38 of 2005 stating that the presiding officers must use their discretion in dealing with cases. This causes a huge challenge in that presiding officers in one magisterial court interpret the Act differently from those in another district. However, it is not only the lack of uniformity in one magisterial court that is a concern. Participants also stated that they work with presiding officers in different magisterial districts who have completely different ways of handling and approaching matters. This therefore frustrates social workers in that they always have to be conscious of which court they are going to and what the specific procedures of that particular court entail. The challenges, views and experiences of participants on the lack of uniformity of presiding officers are reflected in the following comments:

"The Act goes with regulations and from jurisdiction to jurisdiction, for instance between Benoni and Johannesburg, the implementation of the Act or the interpretation of the Act is different depending on how the presiding officer understands the Act, so you are asked for certain things in one court that may not be required in the next."

"When approaching the courts in terms of the attachments they need on the reports, specifically section 159 reports for the extension of orders, where you find that the Johannesburg Court presiding officers have a set of attachments that they require but if you go to the Alexandra court or if you go to Alberton court, they have different attachments that they need and my understanding is that in the regulations, it is left to the discretion of the presiding Officer, so the fact that there is no uniformity in terms of the attachments that are required by different courts, makes it very difficult and it's a cumbersome process that we are encountering because now we have to either memorise or we have to come up with lists of what is required, at which particular court and that makes it very difficult to organise ourselves administratively in terms of those needs."

\section{Presiding officers who are not well versed on the provisions of the Children's Act}

Most participants stated that they face the challenge of having to deal with presiding officers who are not well versed in the provisions of the Children's Act and who are not experienced in working with children. They stated that the Children's Court matters are often presided over by magistrates who are borrowed from other courts and then often rotated, resulting in some of them not being well versed in the provisions of the Children's Act 38 of 2005. The participants further stated that presiding officers read the Act during the court hearing sessions; at times they quickly run to a presiding officer 
next door to ask for clarity on how certain issues are handled and even ask the social worker on what they should do. The challenges for social workers regarding presiding officers who are not well versed in the provisions of the Act are evident in the following comment:

"When they are not experienced in dealing with children, they become very technical and very impersonal so then the court becomes too intimidating for the child, which should not be the case, so, I think there is need for a training of specialised presiding officers so that we do not have an issue of officers coming from other courts."

\section{Unrealistic demands from presiding officers}

The majority of participants indicated that presiding officers often burden them with unrealistic demands; for instance, they are ordered to ensure that children who are not doing well at school go for educational assessments; yet that is the role of the school authorities that social workers have no control over. At times when the children are not doing well at school, the presiding officers order that they be placed in special schools. However, there is a huge shortage of special schools. Moreover, it is also not the role of the presiding officer or the social workers to make such decisions; it is the role of the education authorities, since they are experts in the field. A number of participants said that they are requested to order teachers around by the presiding officers who think that they know everything, "yet the presiding officers are not experts in the field of education."

Most participants indicated that some of the documents that the presiding officers want them to attach to the reports are not necessary at all, for example, the SASSA extract to prove that the foster mother is getting a foster care grant; school reports for the past four terms and copies of all the previous extension orders. A significant number of participants stated that presiding officers demand that they (social workers) advertise for the biological parents to come forward. This is the case even for children who have been in alternative care for the past 16 years, who were abandoned as newly born babies and whose biological parents' identities and whereabouts have never been known, and who also do not even know the name of the child, since the child would have been given an assumed name and surname. According to social workers, this is "ridiculous and an unnecessary waste of time and resources."

"There are some attachments which really do not make any sense and there is duplication of efforts in that you send these attachments every two years, for example, a certified copy of a birth certificate, you have to send a copy of that each and every time you approach the court and you also have to give them copies of court orders, which they already have in their files, so that really becomes a challenge, administratively."

"There are demands from presiding officers that are beyond our scope of work, especially the demand that we take an active role in the educational assessments of children, of which that matter should be addressed by the educators in 
schools and not by us as social workers, but the presiding officers push the social workers to the extreme."

\section{Presiding officers look down upon social workers}

A number of participants indicated that presiding officers look down upon them, often talk to them in a demeaning manner and embarrass them in front of clients.

"Some of the presiding officers, I think they don't really know how to deal with social workers because they actually tend to look down upon us."

Furthermore, presiding officers often doubt the decisions of social workers and reject requests and recommendations from social workers.

"Instead of the process being collaborative, it becomes competitive, whereas others [presiding officers] want to show that they have more power than others [social workers]. Some are lesser human beings, or are second-class professionals, so to say."

\section{Insufficient number of presiding officers}

Some participants stated that there is an insufficient number of presiding officers in the children's court to the extent that they end up being in court for the whole day to present just one case. What is more frustrating for them is that they are all ordered to be in court by $8 \mathrm{am}$, when they only get attended to perhaps at $12 \mathrm{pm}$, so they spend many hours doing nothing, waiting in a very long queue, which is counter-productive. At times, when a presiding officer who had ordered a monitoring report is not at work on that particular day, cases are just postponed because the other presiding officers do not want to touch the case because of their own heavy case loads. The participants' frustrations are captured in the following words:

"There is a few number of presiding officers to an extent that social workers end up waiting on a queue for two or three hours before they are attended to and I feel that if children are a priority, the children's court is a priority, we need to address things swiftly, we need the correct number of presiding officers who can attend to social workers, or at least a schedule that makes it easier and convenient for social workers to attend court, because it is an inconvenience for social workers to spend the whole day in court."

\section{Attitude of social workers}

Some participants were of the opinion that a successful implementation of the new Children's Act is being undermined by attitudes of some social workers who are used to the old way of doing things. One participant's view summarises this issue as follows:

"Probably, it also boils down to the issue of attitudes, having worked with the old Children's Act, for a very long period of time, their attitude change might be probably taking too long to adapt to the developmental perspective as prescribed by the new Children's Act." 


\section{Untrained and uncooperative police officers}

The majority of the participants stated that the lack of corporation and insufficient knowledge among the police officers is a huge stumbling block to them in the implementation of the Children's Act. The participants further stated that the police have no clue as to what their responsibilities are as far as implementing the Children's Act is concerned. Furthermore, police officers are not trained to work with children and as a result they intimidate the children. The participants' views on police officers are reported as follows:

"The police know some parts of what their duties are but they are not aware of what the social worker must do when they have finished their part. Some of the police don't even know what to do when they get to an abused child. You find that when children or parents go to the police to report child abuse, they are dismissed from the police station, they are told [to] go away."

"I think the police are not doing the risk assessment, they just remove children."

Other than the above-discussed institutional challenges, the participants also revealed infrastructural challenges in implementing the Children's Act 38 of 2005. These infrastructural challenges will be next discussed.

\section{Theme 3: Infrastructural challenges in the implementation of the Children's Act}

Several participants indicated that they are facing numerous infrastructural challenges in the implementation of the Children's Act. These infrastructural challenges stem from the unavailability of resources, which is a result of poor funding of the child protection sector. The consequence of poor funding is that it places restrictions on the use of telephones, computers, fax machines and vehicles. These restrictions make social workers fail to adequately execute services as advocated for by the Children's Act 38 of 2005. The infrastructural challenges are evident in the following comments:

"There is a lack of resources and this lack of resources emanates from the poor funding of the sector as a whole, with respect to social development and particularly child welfare, because it is difficult to justify whether we are not just a consumer, unlike other sectors which are producing."

"We face a lot of shortages in terms of the resources that we need to execute our duties; for example, we need to contact a lot of collaborative partners, who could be fellow social workers, other professionals and paraprofessionals and to do that, we need to engage, via telephonic conversations; we need to travel to some other places, and in our organisation, it is very difficult because of the restrictions in terms of the use of telephones, the restrictions in terms of access to vehicles and when you can travel and when you can not travel. So, that brings a lot of challenges as a collaborative process also becomes a longitudinal process, and along the way, some of the services are not effectively and comprehensively implemented." 
In an editorial on the Children's Act 38 of 2005, Dawes (2009) states that the said Act is way ahead of the capacity to deliver services at ground level and recommends a significant scaling up of finance and staffing. Research done by September and Dinbabo (2008:118) recommend that for the implementation of the Children's Act 38 of 2005 to be successful, efficient and effective infrastructure needs to be put in place.

\section{Theme 4: Human resource challenges in the implementation of the Children's Act}

A significant number of participants stated that they face a lot of human resource challenges in the implementation of the Children's Act. They explained these as stemming from the shortage of social workers, which inevitably leads to high case loads. The consequence of the shortage of human resources is that it causes delays in responding to emergencies. On the other hand, some participants stated that they end up only responding to crises and neglecting prevention and early intervention services. They also end up rendering services in a remedial manner as opposed to the comprehensive developmental services that are legislated for in the Children's Act. Some participants felt that social workers were not adequately trained on the Children's Act. Sub-themes which emerged from human resource challenges will be discussed next.

\section{Shortage of social workers, high case loads and poor salaries}

The experiences of most participants regarding the human resource challenges that they face in the implementation of the Act stem from high caseloads; an inadequate number of social workers; and their poor salaries. These three issues are intertwined as reflected in the following views of participants:

"The reality in the social welfare service is that the field has got [a] high staff turnover. We have government, which is offering better opportunities for social workers, so we will always have a consistent migration of social workers from the NGO sector being absorbed into government and that leaves a lot of gaps in the NGO sector."

"Implementation is a challenge, because we are working with a population of over 49 million and we have a drop in the ocean number of social workers, who are supposed to render, not only child protection services, but also family preservation services, services for persons living with disabilities and a lot of other welfare sectors."

According to the South African Institute of Race Relations (SAIRR) (2012:1), the total number of social workers registered with SACSSP in March 2012 was 16740 . This number includes social workers who work for the government; non-profit organisations, the private sector, as well as those who are no longer in practice but retain their registration status. Of these 16740 registered social workers, "Only 6655 (40\%) are employed by government and 2534 (16\%) by NPOs." (SAIRR, 2012:1). This leaves $7451(45 \%)$ registered social workers who are either not practising or are employed in the private sector. Clearly the number of social workers is inadequate for the successful implementation of the Children's Act 38 of 2005. Proudlock and Debbie (2011:2) state 
that "Between 16000 and 66000 social workers providing direct welfare services for the Children's Act alone are urgently needed in the country." SAIRR (2012:1) postulates that about 16504 social workers are required to implement the Children's Act effectively. This accounts for $99 \%$ of all registered social workers, illustrating the huge shortage of social workers in the country.

\section{Inadequate training of social workers}

Besides the shortage of social workers, a few participants highlighted that social workers did not receive enough training on the Children's Act and that is why it is very difficult to implement it, because they do not know its provisions and regulations.

"Some social workers are not well trained on the Children's Act, the new Act, because some are still familiar with the old Act, and are not yet familiar with the new Act and it is very difficult for them to implement it."

"The Act was introduced too quickly. I for one never received any training on how to implement the Children's Act. I would have thought that something as huge as the new legal system is introduced; people should be adequately trained to know the new system in and out. I for one have been kind of like operating in the dark; it has been on a trial and error basis and I have made a lot of mistakes."

What is needed is a paradigm shift, "acknowledging that old ways of doing things may not be the best" (September \& Dinbabo, 2008:121). Patel (2005:3) adds that moving from an old way of doing things is always challenging and it causes considerable tension and uncertainty.

\section{Theme 5: Shortcomings of the Children's Act 38 of 2005}

The majority of the participants stated that some of the challenges they face in implementing the Children's Act relate to the shortcomings of the Children's Act 38 of 2005; loopholes within the Act itself; and some terms and concepts in the Children's Act that are unclear and ambiguous. These include, among others, transfer of children to alternative placements; problems relating to section 150(1) of the Children's Act 38 of 2005 (ground for finding that a child is in need of care and protection, which states that a child is in need of care and protection if the child has been orphaned or abandoned and is without any visible means of support); and the fact that the child protection system is very slow in processing cases that pass through it.

"What does rectify mean, for example? An order issued by the Department of Social Development is invalid when the order has not yet been rectified. And then probably issues of interpretation of terms in the Children's Act, in terms of visible means of income. What does that imply? It's a relative term, which can be interpreted differently between all the partners engaged in this collaborative approach."

"A lot of elaboration is needed to really make a clear distinction of who is a child in need of care. We need a lot of explanation in order to make it very clear; it also mean that social workers need to attend a lot of workshops 
because you find that in some cases where the child was removed in terms of section $150(a),(f)$ and $(g)$, they overlap each other so at times you find that social workers are confused over which sections to use, is it $(f)$ or $(g)$ or it is both sections. You cannot choose $g$, for example, and leave $f$ because they complement each other, so in some cases the social workers opted only for $(f)$ or $(g)$, and this shows a doubt in implementation; it shows a doubt in saying whether a child is in need of care and protection or not."

\section{Theme 6: Addressing challenges in the implementation of the Children's Act}

The participants proposed numerous solutions to addressing the challenges they face in the implementation of the Children's Act 38 of 2005, which will be discussed under the following sub-themes.

\section{Establishing a kinship care grant}

Most participants stated that their case loads are unnecessarily high due to the fact that they have cases for children who passed though the formal foster care system so as to access foster care grants. The majority of the participants are of the view that this can be ameliorated by establishing a kinship care grant. This would be for children in the care of relatives who are basically in need of cash and not as much in need of care, and who generally go through the formal foster care system in order to access a grant.

"There are too many children that are going through the formal foster care system. I think it's actually prudent if we have a parallel system that can actually capture some of the children, especially the related placements, so that they don't go through the statutory processes that foster children go through, so that they can actually have their own sort of grant that is administered differently from the foster care grant, so that we reduce pressure on the conventional foster care system."

\section{Amending the Children's Act 38 of 2005}

All participants were of the view that most problems that they face in implementing the Children's Act 38 of 2005 can be addressed by amending the Act itself. They stated that the Act should clarify the meaning of certain terms and definitions, for example, the phrase "visible means of support", "ratify", "orphaned" and many other terms.

"I think there is need for more clarity, or even revisit the phrase [A child is in need of care and protection if the child has been abandoned or orphaned and is without any visible means of support] itself to bring clarity to that."

\section{Taking administrative extension of orders back to the Department of Social Development}

Participants were of the opinion that the administrative extension of orders should be taken back to the Department of Social Development. They stated that this would solve all the problems that they experience with the children's courts.

"I think the issue of the administrative function of extending orders, I think it is actually more better that they are returned to the Department of Social 
Development, so that people do not need to frequent the courts on a daily basis for something that can be done in their absence. So it is actually better if they return that administrative function to where it was before, which is the Department of Social Development, then we will not have an issue of dealing with different courts, spending unnecessary time at court, the issue of different courts having different requirements, this would make life easier."

\section{Addressing problems with presiding officers}

Of significance is the fact that most problems that the majority of participants face in implementing the Children's Act 38 of 2005 seem to be caused by the presiding officers. Therefore, the majority of the participants stated that problems with presiding officers should be addressed:

"We should have regular meetings or monthly meetings with the representatives of the Children's Court, especially with the magistrates, where social workers should attend, together with the police and any other authorised officers who are involved in the implementation of the Children's Act."

"I think periodicals would do. Just as much as doctors would meet to discuss and afterwards release periodicals about new drugs and whatnot, social workers should do the same."

"We need to address things swiftly; we need the correct number of presiding officers who can attend to social workers, or at least a schedule that makes it easier and convenient for social workers to attend court, because it is very inconvenient for social workers to spend the whole day in court."

\section{CONCLUSIONS}

Although the social workers have awareness of some features and key principles of a developmental approach, and some participants were able to contextualise child protection within the Children's Act 38 of 2005 from a developmental perspective, the provisions of this Act are not fully implemented within a developmental paradigm. Lombard and Kleijn (2006:214) argue that, "The first step towards statutory social service delivery within a developmental approach is recognising that statutory services are included in the basket of developmental social welfare service delivery." Having some knowledge on where statutory services fit within a developmental approach is a good start towards shifting towards a developmental approach in child protection services (Lombard \& Kleijn, 2006).

Institutional obstacles that participants face in implementing the Children's Act 38 of 2005 stem from the attitude of social workers who are not well versed in the provisions of the Children's Act and who are not implementing services from a developmental perspective. Successful implementation of the Children's Act requires a paradigm shift and a change of attitude among social workers (Mbambo, 2004).

Social workers are the victims of the Children's Court system, which they do not challenge in the interest of effective child protection services. Findings show that most institutional barriers in implementing the Act stem from the presiding officers who lack 
uniformity, who are not well versed in the provisions of the Act, look down upon social workers and overburden them with unrealistic demands. Infrastructural barriers inhibit effective child protection services and make developmental child protection services a "pipe dream". Social workers should take a critical stance against the presiding officers to stand up for their rights. Adams (2002) argues that social workers should become more critical practitioners and respond to oppressive behaviour.

Some of the institutional challenges that most participants face stem from actions of untrained and uncooperative police officers who do not know how to fulfil their roles and obligations. The police officers often remove children from their families due to poverty, even though the children might not be in need of care and protection. This is probably due to the fact that they did not receive adequate training on the Children's Act. UN guidelines for the alternative care of children (2009:7) clearly state that "Financial and material poverty, or conditions directly and uniquely imputable to such poverty, should never be the only justification for the removal of a child from parental care ... but should be seen as a signal for the need to provide appropriate support to the family."

The infrastructural barriers that most participants face in implementing the Children's Act 38 of 2005 stem from the unavailability and restricted use of resources. The shortage of resources seems to stem from the poor funding of child protection organisations. Efficient and effective infrastructure including office space, drop-in centres, children's homes, vehicles and office equipment such as telephones, computers and fax machines are required to implement the Children's Act (September \& Dinbabo, 2008).

The Children's Act cannot be fully implemented in the absence of sufficient numbers and capacity of social workers. Social workers face enormous human resource challenges in the implementation of the Children's Act stemming from the shortage of social workers, inadequate training of social workers and high case loads. These findings correspond with what is stated in the literature, namely that due to resource constraints, social workers, as a consequence of a high work load, low salaries and poor working conditions, are leaving the profession or the country to work abroad (Earle, 2008). The poor and inadequate working conditions for social workers are an ongoing issue. A study by Alpaslan and Schenck (2012:374-376) found that social workers work in environments characterised by lack of offices, inadequate office equipment, shortage of vehicles, high caseloads and a shortage of staff. September and Dinbabo (2008) note that social workers are the ones to turn the Children's Act into a lived reality for children and their families. A study by Naidoo and Kasiram (2006) found that social workers in South Africa generally deal with over 120 cases (compared with a maximum of about 12 cases in the UK). This leads to high levels of stress and frustration among social work professionals (Earle, 2008).

Shortcomings that some participants have realised in the implementation of the Children's Act 38 of 2005 relate to the transfer of children to alternative placements; different interpretations of different sections of the Act; and the over-reliance of the child protection system on foster care structures to provide income support to children. 
The findings on challenges relating to the ambiguity and subjective grounds of finding that children are in need of care and protection as outlined in section 150(1) of the Children's Act, are confirmed by Hall and Proudlock (2011:2), who state that most presiding officers reject recommendations made in terms of section 150(1)(a), saying, "The child is not without 'visible means of support' as required by section 150(1)(a)."

Challenges that social workers are facing in the implementation of the Children's Act can be effectively addressed by establishing a kinship care grant; amending the Children's Act; organising training for all role players involved in implementing the Children's Act; increasing salaries of social workers; taking administrative extension of orders back to the Department of Social Development; and encouraging cooperation and collaboration between various role players involved in the implementation of the Children's Act. Loffell (2011) concurs that a simple introduction of a kinship care grant can ameliorate this terrible predicament of going through the formal child protection system in order to access a foster care grant. To deal with the burden on the foster care system, the Department of Social Development should conduct a comprehensive review of the social security policy for children and the foster care system as requested by the Portfolio Committee on Social Development in its report on the Amendment Bill (Proudlock \& Jamieson, 2008:39).

\section{RECOMMENDATIONS}

Recommendations to address the challenges faced by social workers working in child protection services in implementing the Children's Act 38 of 2005 are outlined below.

The regulations of the Social Assistance Act 13 of 2004 should be amended to allow for a kinship care grant which would cater for orphans in the care of relatives. This will replace the use of the inaccessible foster care grant for this category of children and therefore ensure that the majority of orphans living in poverty with family members receive an adequate grant efficiently and timeously. By providing a kinship care grant, the use of the foster care grant for orphans in the care of relatives will be reduced. This will also lighten social workers' case loads and therefore enable improved prevention, as well as early intervention and protection services for abused and other vulnerable children.

Numerous sections of the Children's Act should be amended. Section 42(3) should be amended to state that the Minister of Justice and Constitutional Development and the head of the administrative region "must" appoint a dedicated presiding officer, instead of "may". The phrase "who meets the prescribed requirements" should be included after "magistrate or additional magistrate" to ensure that the presiding officer has the requisite training. Moreover, it should be a permanent position and should not be rotated in order to counteract the lack of experience of rotating magistrates resulting in procedural difficulty and irregularity in the application of the Act. Section 150(1)(a) should be amended to remove the words "and is without any visible means of support" and replace them with the words "abandoned or orphaned and not in the care of a family member." The effect of this would be that children who are abandoned or orphaned, but who are nevertheless living with a family member (who is not a biological parent), are not 
automatically in need of care and protection. The proposed amendment to section 150 would create a system that allows for non-court-ordered care by relatives, namely, the kinship care grant as discussed above.

The Department of Social Development must take responsibility to train all the role players involved in the full implementation of the Children's Act. Furthermore, the presiding officers, the police and social workers should attend the same training workshops and be trained by the same trainers so that everyone is clear about their roles and obligations.

Regular meetings between the presiding officers of the Children's Court, police officers and social workers involved in the implementation of the Children's Act should be conducted. During such meetings these three stakeholders should deliberate on issues of importance, address their mutual respective expectations, and discuss the possible challenges.

Social workers should be trained in the practical application of a developmental approach in the rendering of child protection services. Once the social workers have been trained on how to render services in a developmental fashion, then sufficient resources need to be available to them by the Department of Social Development.

The administrative extension of orders in terms of section 159 and section 186 should be taken back to the Department of Social Development. This would solve most problems that social workers encounter with courts regarding the extension of placements orders. Moreover, it would free up the valuable time of the presiding officers of Children's Courts to enable them to fully focus on other duties that have a direct bearing on the protection of children.

For the implementation of the Children's Act to be successful, efficient and effective, suitable infrastructure needs to be put in place; this includes office space, drop-in centres, children's homes, vehicles and office equipment such as telephones, computers and fax machines.

To deal with the burden on the foster care system, the Department of Social Development should conduct a comprehensive review of the social security policy for children and the foster care system as requested by the Portfolio Committee on Social Development in its report on the Amendment Bill (Proudlock \& Jamieson, 2008:39).

\section{REFERENCES}

ADAMS, R. 2002. Developing critical practice in social work. In: ADAMS, R., DOMINELLI, L. \& PYNE, M. (ed). Critical practice in social work. New York: Palgrave.

ALPASLAN, N. \& SCHENCK, C. 2012. Challenges related to working conditions by social workers practising in rural areas. Social Work/Maatskaplike Werk, 48(4):367386.

Centre for Child Law v Minister of Social Development and others. 2011a. (North Gauteng High Court) Case number 21726/11. Order of 10 May 2011, unreported. 
Centre for Child Law v Minister of Social Development and others. 2011b. (North Gauteng High Court) Case number 21726/11. Order of 08 June 2011, unreported.

CHILD CARE ACT 74 OF 1983. Published in the Government Gazette (8465). Pretoria: Government Printer.

CHILDREN'S ACT 38 OF 2005. Published in the Government Gazette (28944). Pretoria: Government Printer.

Chirindza and others $v$ Gauteng Department of Health and Social Welfare and others. 2011. JOL 27290 (GNP).

CONSTITUTION OF THE REPUBLIC OF SOUTH AFRICA. Pretoria: Government Printer.

CRESWELL, J.W. 2009. Research design: qualitative, quantitative and mixed method approaches $\left(3^{\text {rd }}\right.$ ed). Thousand Oaks, California: Sage Publications.

DAWES, A. 2009. The South African Children's Act. Journal of Child and Adolescent Health, 30(10):iv-vi. Cape Town: University of Cape Town.

DEPARTMENT OF JUSTICE AND CONSTITUTIONAL DEVELOPMENT. 2010. Regulations Relating to Children's Courts and International Child Abduction. Government Gazette 33067. Pretoria: Government Printer.

DEPARTMENT OF SOCIAL DEVELOPMENT. 2006. Integrated Service Delivery Model towards improved social services. RP31. Pretoria: Government Printer.

DEPARTMENT OF SOCIAL DEVELOPMENT. 2010. Consolidated Regulations Pertaining to the Children's Act, 2005. Government Gazette 33076. Pretoria: Government Printer.

DEPARTMENT OF SOCIAL DEVELOPMENT. 2011. Framework for provision of developmental social welfare services (Draft). Pretoria: Government Printer.

EARLE, N. 2008. Social work as a scarce and critical profession. Research consortium.

GREEFF, M. 2011. Information collection: interviewing. In: DE VOS, A.S. (ed) STRYDOM, H., FOUCHÉ, C.B. \& DELPORT, C.S.L. Research at grass roots: for the social sciences and human service professions $\left(4^{\text {th }}\right.$ ed). Pretoria: Van Schaik Publishers.

HALL, K. \& PROUDLOCK, P. 2011. Orphaning and the foster child grant: a return to the 'care or cash' debate. Children Count Brief. Cape Town: Children's Institute, University of Cape Town.

HÖLSCHER, D. 2008. The emperor's new clothes: South Africa's attempted transition to developmental social welfare and social work. International Journal of Social Welfare, 17(2):114-123. 
LOFFELL, J. 2011. Interview with Jackie Loffell, a social policy expert who was involved in drafting the Children's Act 38/2005 (as amended). [Transcript]. 17 August. Johannesburg.

LOMBARD, A. \& KLEIJN, W.C. 2006. Statutory Social Services: an integral part of developmental social welfare service delivery. Social Work/ Maatskaplike Werk, 42(3/4):213-233.

LOMBARD, A. 2010. Integrated developmental Social Welfare. Paper presented at a National Indaba on Integrated Developmental Social Welfare Services, 3-5 February, Birchwood Executive Hotel and Conference Centre, Boksburg.

MBAMBO, B. 2004. How to ride a wave when the tide turns? Children First, 8(57):3940.

NAIDOO, S. \& KASIRAM, M. 2006. Experiences of South African social workers in the United Kingdom. Social Work/Maatskaplike Werk, 42(2):117-126.

NEUMAN, W.L. 2000. Social research methods: qualitative and quantitative approaches $\left(3^{\text {rd }}\right.$ ed). Boston: Allyn \& Bacon.

NEWS24. 2011. Court order to end foster care crisis. 10 May. [Online] Available: http.//www/news24.com/SouthAfrica/News/ourt-Order-to-end-foster-care-crisis.

[Accessed: 15/12/2011].

PATEL, L. 2005. Social Welfare and Social Development in South Africa. Southern Africa: Oxford University Press.

PATEL, L. 2008. Getting it right and wrong: an overview of a decade of Post-Apartheid Social Welfare. Social Work in Action, 20(2):71-81.

PROUDLOCK, P. \& DEBBIE, B. 2011. Implementing the Children's Act: analysis of human resource capacity and constraints. Cape Town: Children's Institute, University of Cape Town.

PROUDLOCK, P. \& JAMIESON, L. 2008. The Children's Act: providing a strong Legislative foundation for a developmental approach to child care and protection. Cape Town: Children's Institute, University of Cape Town.

REPUBLIC OF SOUTH AFRICA. 1996. The Constitution of the Republic of South Africa. Act 108 of 1996. Pretoria: Government Printer.

REPUBLIC OF SOUTH AFRICA. 1997. Ministry of Welfare and Population Development. White Paper for Social Welfare. Government Gazette, Vol. 386 (18166). Pretoria: Government Printer.

REPUBLIC OF SOUTH AFRICA. 2007. Proclamation 13; Children's Act (38/2005): Commencement of certain sections. Government Gazette No 30030. Pretoria: Government Printer.

RUBIN, A. \& BABBIE, E. 2011. Research methods for social work $\left(7^{\text {th }}\right.$ ed). Belmont: Cengage Learning. 
SEPTEMBER, R. \& DINBABO, M. 2008. Gearing up for implementation. A new Children's Act for South Africa. Practice: Social Work in Action, 20(2):113-122.

SIBANDA, S. 2013. Challenges faced by social workers working in child protection services in implementing the Children's Act 38 of 2005. Pretoria: University of Pretoria. (MSW Mini-Dissertation)

SOUTH AFRICAN COUNCIL FOR SOCIAL SERVICES PROFESSIONS. 2013. February/March 2013 Newsletter, 2(2). [Online] Available: www.sacssp.co.za [Accessed: 27/04/2013].

SOUTH AFRICAN INSTITUTE OF RACE RELATIONS (SAIRR). 2012. Social worker shortage undermines effectiveness of social welfare legislation. [Online] Available: www.sairr.org.za [Accessed: 14/08/2012].

UNICEF. 1990. First call for children. New York: UNICEF.

UNITED NATIONS GUIDELINES FOR THE ALTERNATIVE CARE OF CHILDREN. 2009. [Online] Available: www.iss-ssi.org/2009/asserts/filesd/guidelines. [Accessed: 29/11/2011].

UNITED NATIONS. 1989. United Nations Convention on the Rights of the Child. UN General Assembly Document A/RES/44/25. New York: UN.

VAN NIEKERK, H.J. 1998. Child welfare legislation and practice. Durbanville: Van Gent Publishers.

WEXLER. R. 2003. The road less travelled by: towards real reform for child welfare in Missouri ( $2^{\text {nd }}$ ed). Alexandria VA: National Coalition for Child Protection reform. [Online] Available: http://www.nccpr.org/missourireport5.doc [Accessed: 24/08/2010].

Mr Sipho Sibanda, postgraduate student; Prof Antoinette Lombard, Department of Social Work \& Criminology, University of Pretoria, Pretoria, South Africa. 